\title{
Kelkit Vadisinin Aşağı Çığırında Gelişmiş Heyelanların Dağılım Deseni ve Oluşumlarını Kontrol Eden Faktörler
}

\section{Distribution pattern and factors controlling the formation of landslides in the downstream part of the Kelkit Valley}

\author{
Mehmet Emin Cihangir*ab Tolga Görümª \\ ${ }^{a}$ Istanbul Üniversitesi, Edebiyat Fakültesi, Coğrafya Bölümü, İstanbul. \\ ${ }^{b}$ Kahramanmaraş Sütçü Imam Üniversitesi, Fen Edebiyat Fakültesi, Coğrafya Bölümü, Kahramanmaraş.
}

\section{MAKALE BILGI}

Geliş/Received: 01.02.2016 Kabul/Accepted: 09.03.2016

Anahtar Kelimeler:

Heyelan

Dağılımı deseni

Yamaç süreçleri

Jeomorfoloji

Kelkit

\section{Keywords:}

Landslide

Distribution pattern

Hillslope processes

Geomorphology

Kelkit

*Sorumlu yazar/Corresponding author (M.E.Cihangir) m.e.cihangir@gmail.com

http://dx.doi.org/10.17211/tcd.84731

\section{ÖZ / ABSTRACT}

Kelkit Çayı, Kuzey Anadolu Fayı tarafindan kontrol edilen son derece çizgisel bir vadi şekline sahiptir. Litolojik geçişlerin keskin, topoğrafik rölyef ve eğimin yüksek olduğu bir sahadır. Çalışma alanını oluşturan Kelkit Çayı'nın aşağı çığııı (Umurca-Koyulhisar arası) tektonik ve jeomorfolojik süreçlere bağlı gelişen heyelanların yoğun olduğu bir bölgedir. Çalışmanın amacı heyelan tehlikesinin yüksek olduğu bu alanda heyelanların jeolojik ve jeomorfolojik koşullara bağlı dağılım karakteristiğini ortaya koymaktır. Bu doğrultuda yüksek çözünürlüklü (SPOT, WorldView) uydu görüntülerinden oluşturulan heyelan envanterinin doğruluk kontrolleri arazi çalışmaları ile sağlanmıştır. Çalışma alanında 0.004$23.2 \mathrm{~km}^{2}$ arasında değişen 433 heyelan belirlenmiştir. Bu heyelanlar; akma, düşme, kayma tipinde olmak üzere üç ana sınıf altında haritalanmıştır. Heyelan tiplerinin eğim, rölyef, yükselti değer aralıklarında farklı dağııım gösterdikleri, litolojik olarak ise heyelanların Eosen volkanik çökel kayalarda ve Maestrihtiyen kireçtaşlarında yoğunlaştiğı tespit edilmiştir. Özellikle birçoğunun kaya düşmeleri olduğu küçük heyelanların faya yakın zonlarda meydana geldiği tespit edilmiştir. Çalışmada haritalanan heyelanların belirli bir topoğrafik eğim ve rölyef değerleri arasında dağıldıkları ve jeomorfolojik açıdan geliştikleri alanların rastlantısal olmadığı, üst kesimlerde daha düze yakın plato aklanında ve paleo-heyelan topoğrafyaları içerisinde biriken karların ani erimesinin bu sürecin heyelanların tetiklenmesindeki ana neden olduğu ortaya konmuştur.

Kelkit Creek is a highly linear valley controlled by North Anatolian Fault. The region has high topographical relief and slopes with sharp lithological transitions. Landslides due to tectonic and geomorphological processes are common in the downstream part of Kelkit Creek (between Umurca-Koyulhisar), which is the study area. The aim of the study is to reveal the distribution characteristics of the landslides driven by geological and geomorphological conditions in this highly landslides prone region. For this purpose, the accuracy of the landslides inventory obtained from high-resolution satellite images (SPOT, WorldView) was verified via field studies. In the study area, 433 landslides with sizes ranging 0.004-23.2 km² and types of flow, fall and slides were mapped. It was detected that the distribution of the landslides was different for different slope, relief and elevation ranges. Also, we found out that the landslides were concentrated in Eocene aged sedimentary rocks and Maastrichtian aged limestones. Moreover, we detected that small-sized landslides (especially rock-falls) occurred in zones nearby the fault line. According to the study it was revealed that the distribution of the mapped landslides in the study area was not arbitrary and they were found to be concentrated in certain slope and relief ranges. Finally it was found that the sudden melting of the accumulated snow in the higher altitude plateau catchments and in the paleo-landslide topographies was the main triggering factor for the formation of landslides.

\section{Giriş}

Bir yamaç eğimi boyunca kaya, moloz ve toprak gibi yamac oluşturan malzemelerin hareketine heyelan denir (Varnes, 1958). Heyelanlar deprem, yağış gibi doğal ya da antropojenik ve yapay sarsıntılara bağlı etkenlerle oluşabilmektedir. Heyelan oluşumunu litolojik, morfolojik, yapısal vb. faktörler duyarlı kılmaktadır. Heyelanlar yağış, deprem, litolojik ve topoğrafik koşullara bağlı olarak tip ve yoğunluk bakımından lokal ve bölgesel farklılıklar göstermektedirler. Heyelanların bu değiş- kenliğini eğim, litoloji, rölyef, yükselti, yeraltı su seviyesi ve yapısal faktörler kontrol etmektedir (Guzzetti vd., 1999; van Westen vd., 2006; Gorum vd., 2008; Bayrakdar ve Görüm, 2012; Nefeslioglu vd., 2013).

Heyelanların yoğun olduğu bir bölgede faktörlerin farklılık göstermesinin yanında heyelanın tipindeki değişim, heyelanı meydana getiren koşulların farklılığını da göstermektedir (Varnes, 1958; Hungr vd., 2014). Morfolojik ve litolojik farklılıklar ve he- 
yelanı tetikleyen farklı hidro-meteorolojik ve sismik olayların büyüklüğü oluşan heyelanların yoğunluğunda, dağılım deseninde ve büyüklüğünde farklılıklara neden olmaktadır (Larsen ve Torres-Sánchez, 1998; Gorum vd., 2014). Bu nedenle heyelan dağılımını kontrol eden faktörleri çok geniş alanları kapsayan çalışmalarda belirlemek oldukça zordur (Guzzetti vd., 2007). Topoğrafik bakımdan eğim ve rölyef'in heyelan dağılımı üzerindeki kontrolü baskındır. Büyük heyelanlarda (heyelan alanı>0.5 km²) topoğrafik rölyef' in ve yapısal faktörlerin heyelan büyüklüğü üzerindeki kontrolü alansal bakımdan daha küçük heyelanlara göre belirgindir (Korup 2005, 2007; Blöthe, 2015). Heyelanı meydana getiren koşullar kadar heyelanı tetikleyen faktörlerin de dağılım ve büyüklük üzerinde etkisi vardır. Örneğin depremin odak noktasından ve faydan uzaklaştikça heyelan yoğunluğu ve büyüklüklerinde belirgin farklılıkların olduğu birden fazla çalışmada ortaya konulmuştur (ör. Owen vd., 2008; Dai vd., 2011; Görüm vd., 2011). Benzer şekilde yağış ve tayfunlar gibi hidro-meteorolojik doğal tetikleyiciler de heyelan dağılım karakteristiği üzerinde doğrudan etkilidir (Dai ve Lee 2001; Görüm vd., 2008; Wu vd., 2011; Regmi 2014).

Geniş alanlar için bölgesel heyelan dağılımı ve heyelana ilişkin süreçlerin değerlendirilmesi ancak 1980'li yıllardan sonra mümkün olmuştur. 1980 yıllardan itibaren, Coğrafi Bilgi Sistemleri (CBS) alanındaki gelişimlere paralel olarak bölgesel heyelan analizleri ve heyelanları kontrol eden çoklu faktörlerin bir arada değerlendirilmeleri yaygınlaşmıştır (Gökçeoğlu ve Ercanoğlu, 2001; Korup ve Stolle, 2014). Bu alandaki söz konusu gelişmeler aynı zamanda heyelan duyarlıı çalışmalarının da artmasına ve bu yönüyle mekânsal anlamda heyelanın hangi koşullarda ve nerede gelişebileceğine ilişkin kestirim modellerini uygulanabilir kılmıştır. Tarımsal alanlara heyelanların verdiği zararları azaltmak amacıyla geliştirilen ilk bölgesel heyelan duyarlılık çaIışmalarındaki (Brabb vd., 1978; Carrara vd., 1983) ana yaklaşım Aktüalizm'in öncülerinden Charles Lyell tarafindan tanımlanan "geçmiş geleceğin anahtarıdır" önermesini temel alan "bir bölgede heyelanlar, geçmişte olduğu gibi, gelecekte de aynı jeolojik, jeomorfolojik ve iklim koşulları altında oluşabilir" ifadesidir. Bu bakımdan duyarlılık bir heyelanın mekânsal olabilirliğini ifade eder. Heyelanı kontrol eden doğal koşulları ortaya koymak heyelanın mekânsal ve zamansal olabilirliği açısından son derece önemlidir. Bunun ayrıntılı olarak anlaşılması heyelan duyarlılık ve tehlikesinin tanımlanmasını sağladığı gibi kütle hareketleri süreçlerinin denetimi ile gelişen yer şekillerinin uzun dönem evriminin anlaşılmasına da imkân verir. Kütle hareketlerinin neden olduğu doğrudan veya dolaylı kayıplar dikkate alındığında, koruyucu önlemlerin alınması ve zararları en aza indirgemeye yönelik uygulamalar, mevcut ve potansiyel kütle hareketlerinin alansal dağılım bilgisini, karakteristiğini ve oluşumu kontrol eden faktörlerin bilinmesini gerektirmektedir.

Bu çalışmada tektonik denetimli bir vadi olan Kelkit Çayı vadisinin Umurca - Koyulhisar yerleşimleri arasında kalan kesiminde gelişmiş heyelanların oluşumları, dağılım karakteristikleri ve jeolojik, jeomorfolojik ve hidro-meteorolojik koşulların heyelan dağılımı üzerindeki etkileri incelenmiştir. Çalışmada incelenen heyelanlar yüksek çözünürlüklü uydu görüntüleri ve arazi çalışmalarından yararlanılarak ortaya konulmuştur.

\section{2. Çalışma Alanının Genel Özellikleri}

Çalışma alanı $37^{\circ} 32^{\prime \prime} 40^{\prime}-37^{\circ} 58^{\prime \prime} 00^{\prime}$ E ile $40^{\circ} 22^{\prime \prime} 20^{\prime}-40^{\circ} 9^{\prime \prime}$ $20^{\prime} \mathrm{N}$ koordinatları arasında batıda Umurca ile doğuda Koyulhisar yerleşimleri arasında yer alır (Şekil 1). Çalışma alanı içerisinde 1 ilçe merkezi 17 köy bulunmaktadır. 2015 nüfus verilerine göre alan içerisindeki yerleşimlerin toplam nüfusu 7297'dir (TUík 2015). Ayrıca çalışma alanı içerisinde D-100 Amasya-Erzincan ile D-855 Tokat-Ordu otoyolları bulunmaktadir.

Doğu-bat yönünde akan Kelkit Çayının oluşturduğu havzanın $(10262$ km²) \%3.8'lik bölümünü oluşturan çalışma alanı, Kelkit Vadisinin aşağı çığııında 394.1 km²'lik bir alanı kaplamaktadır. Çalışma alanının havzasının uzun ekseninin $(36.8 \mathrm{~km})$ kısa eksenine (22.4) oranı ise $0.6^{\prime}$ dır.

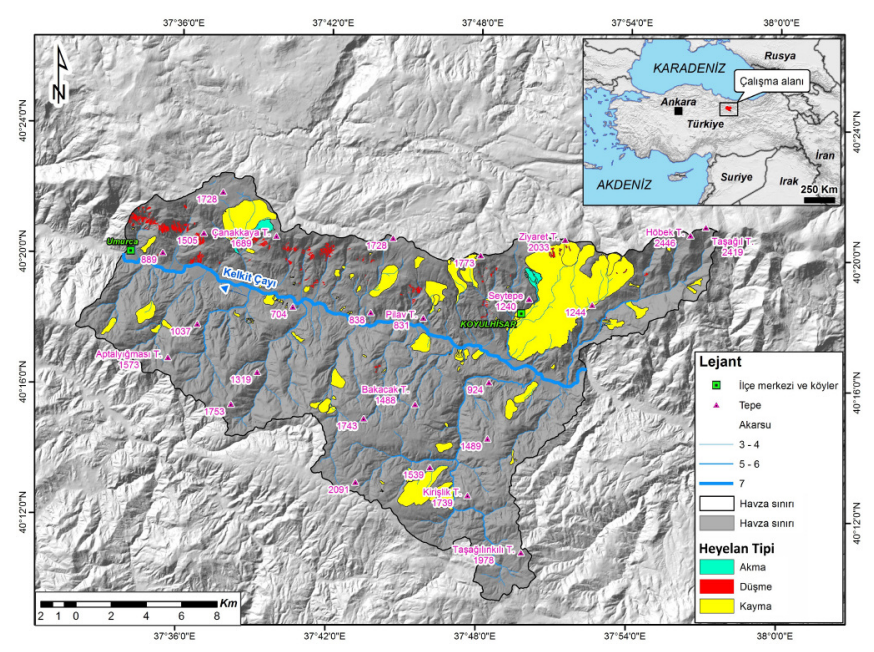

Şekil 1. Çalışma alanının lokasyonu ve heyelan dağılım haritası.

Figure 1. Location of the study area and landslide distribution map.

1953-1994 Devlet Meteoroloji Genel Müdürlüğü 800 m yükseltideki Koyulhisar istasyon verilerine göre havzanın yıllık ortalama sıcaklığı $10.6^{\circ} \mathrm{C}^{\prime}$ dir. Ortalama sıcaklık en yüksek Ağustos $\left(20.5^{\circ} \mathrm{C}\right)$, en düşük ise Ocak $\left(0.8^{\circ} \mathrm{C}\right)$ ayında görülmektedir. Karlı gün sayısı ortalamasının en fazla olduğu Aralık (19 gün) ve Şubat (19 gün) aylarıdır. Maksimum sıcaklıkların ortalaması en yüksek Ağustos $\left(35.4^{\circ} \mathrm{C}\right)$ iken, minimum sıcaklıkların ortalamasının en düşük oluğu ay $-11.7^{\circ} \mathrm{C}$ ile Şubat'tır. Havzada yıllık ortalama yağış 405.6 mm'dir. Toplam yağış ortalaması en yüksek Mayıs (61.6 mm), en düşük ise Ağustos (5.6 mm) ayıdır. Çalışma sahasında gözlenen maksimum günlük yağış 1981 Ekim (62.4 $\mathrm{mm}$ ) ayında meydana gelmiştir. Jeolojik bakımdan havzadaki birimler en yaşlıdan en genç birime doğru şist (Paleozoyik), kireçtaşı (Palezoyik-Mezozoyik), şist (Permiyen-Triyas), serpantinit (Üst Kratese), kireçtaşı (Maestrihtiyen), volkanit-çökel kaya (Üst Kretase), andezit (Santoniyen-Maestrihtiyen), çakıltaşıkumtaşı-çamurtaşı (Alt Paleosen), kireçtaşı (Paleosen), kumtaşı-çamurtaşı-kireçtaşı (Üst Paleosen), kiltaşı (Alt Eosen-Orta Eosen), andezit (Lütesiyen), volkanit-çökel kaya (Eosen), çakıltaşı (Oligosen-Alt Miyosen), kiltaşı (Üst Oligosen-Alt Miyosen), çakıltaşı-kumtaşı-çamurtaşı (Alt Miyosen), bazalt (Pliyosen) ve Kuvaterner' de oluşmuş alüvyonlardır (Yılmaz vd., 1985, Erdem 1987; Keçer ve Tüfekçi 1986). Çalışma alanında değişik fasiyeste kireçtaşı, volkanik/volkano-tortul ve kırıntılı tortul kayaçlar yaygın olarak yüzeylenmektedir. Gevşek dokulu bu kaya birimleri yoğun biçimde ezik, parçalanmış, altere olmuştur 
(Gürsoy vd., 2005; 2006). Kuzey Anadolu Fayı'nın (KAF) bulunduğu kesimde birimler genel olarak yüksek düzeyde deformasyona uğramışlardır (Tatar vd., 2012).

Çalışma sahasında KAF'ın kuzeyinde Üst Kretase kireçtaşı, Pliyosen bazaltları, Eosen ve Üst Kretase volkanit çökel kayaları gibi litolojik birimlerle temsil edilmektedir (Yılmaz vd., 1985; Erdem 1987; Keçer ve Tüfekçi 1986). KAF'ın kuzey batısında, fay zonuna yakın bölümde volkanit çökel kayalar ve Kuvaterner alüvyonları mevcuttur (Şekil 2). Kuzey bölümde Kuzulu Mahallesi kuzeydoğusunda yer alan ve aynı zamanda eski bir heyelan bölgesi üzerinde bulunan Sorkun yaylası kireçtaşlarının egemen olduğu bir temel üzerinde yer yer $45^{\circ}$ ye ulaşan bir eğime sahip yaklaşık 3 km'lik dar bir vadi boyunca, \%90' a andezit bazalt, tüf ve aglomera ve bunlardan meydana gelmiş çakıl taşlarından oluşmaktadır (Gürsoy vd., 2005; 2006). Üst Kretase volkanik ve sedimanter birimler düşük eğimlerde görülürken Maestrihtiyen kireçtaşları ise rölyef ve eğimin yüksek olduğu alanlarda, KAF'ın etkisiyle kısa mesafelerde değişim göstererek kuzeydoğu yönünde eğimlenmişlerdir. Üst kotlardaki Pliyosen volkanik birimler ise; bozunma sonucu önemli kalınlığa sahip bir regolit zonu oluşturmaktadır (Duman vd., 2005). Havzanın güney batısında KAF'a yakın alanda Alt Miyosene ait çakıltaşı-kumtaşı-çamurtaşları bulunmaktadır. Eosen volkanik çökel kayalar havzada güney batıdan kuzey doğuya doğru kesintisiz bir şekilde uzanmaktadır. Havzanın güneyinde ise Üst Kretase serpantinitleri yoğunluk kazanmakta bunların arasında yer yer havzanın en yaşlı birimleri olan Paleozoyik şistler ile Alt-Orta Eosen kiltaşları görülmektedir (Şekil 2).

Jeomorfolojik bakımdan, havza tektoniğin denetiminde gelişmiş ve derine kazmanın yüksek olduğu bir vadi sistemine kar- şılık gelmektedir. Çalışma alanında ortalama eğim $18.6^{\circ}$, en yüksek eğim ise $58.8^{\circ}$ dir. Çalışma sahasının ortalama yükseltisi 1283 m, minimum yükseltisi 561.4 m, maksimum ise 2446.4 m'dir. KAF'ın da etkisiyle Kelkit Çayında yan ve derine aşındırmanın yüksek olması havzada eğim ve topoğrafik rölyefin yüksek olmasına neden olmaktadır (Gökçeoğlu vd., 2005; Yıldırım 2006). Özellikle havzanın kuzeyinde ve güneyinde Kelkit Çayına bağlı yan kolların oluşturduğu " $V$ " tipi vadiler görülmektedir. Taban seviyesini oluşturan çizgisel ve dar kanal eksenine sahip Kelkit Vadisi yüksek eğimlerle temsil edilen yan yamaçlara sahiptir. Bu yamaçların ortalama eğimleri $24^{\circ}$ 'dir. Kuzey ve güney vadi yan yamaçları karşılaştırıldığında güney yamaç kuzeye göre daha diktir. Bu bakımdan Kelkit Vadisi'nin çalışma alanında temsil edilen kısmı asimetrik bir görünüme sahiptir. Bu asimetri büyük ölçüde vadinin güneyinde yer alan KAF tarafindan kontrol edilmektedir. Yüksek eğimli yamaçların güney devamında engebeli topoğrafya su bölüm hattını oluşturan keskin sırt ve tepelerle çevrilidir. Buna karşılık akarsuyun kuzeyinde yer alan kesimde yüksek eğimli ve kütle hareketleri içeren eğimlerin gerisinde yapısal bir düzlük yer almaktadır. Bu yapısal düzlük Maestrihtiyen kireçtaşlarının yüzeylendiği ve içerisinde değişik boyutlarda karstik çukurların bulunduğu bir alandır. Çalışma alanı egemen olarak kütle hareketleri ve flüvyal süreçler tarafindan şekillendirilmektedir.

Kelkit Çayı vadisinde depremlerin yanı sıra özellikle kuzey yamaçlarda yoğunlaşan farklı tip ve büyüklüklerde heyelanlar yer almaktadır. Bu alandaki heyelanların son derece katastrofik oldukları birçok çalışmada rapor edilmiştir (Duman vd., 2005; Gökçeoğlu vd., 2005; Yılmaz vd., 2006). Özellikle bu heyelanlar 1970-2008 yılları arasında saha içerisindeki 11 köy afet boyutu

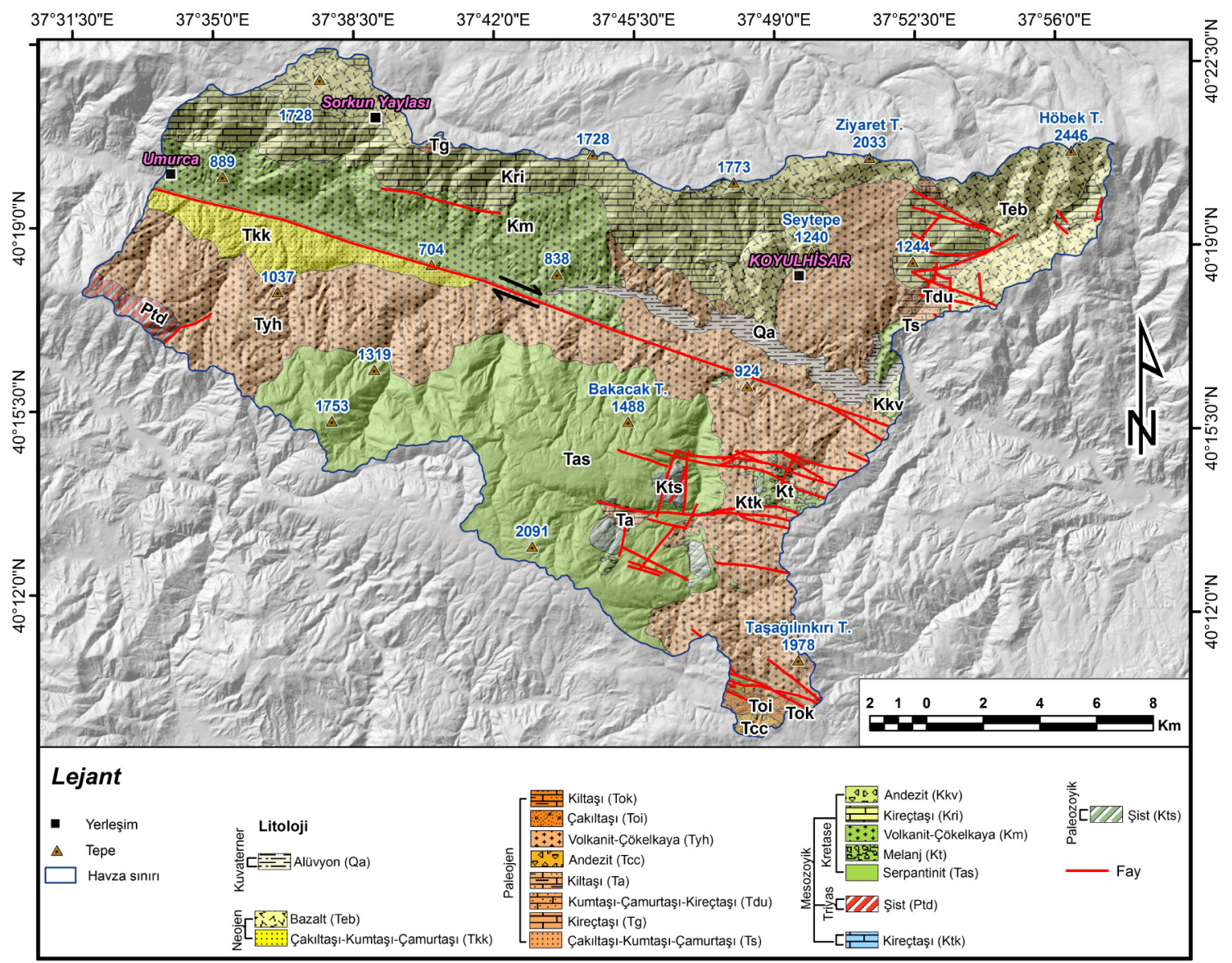

Şekil 2. Çalışma alanının jeolojisi (MTA, 2011 ve Yılmaz vd., 1985'den derlenmiştir).

Figure 2. Geology of the study area (compiled from MTA 2011 and YIlmaz et al. 1985). 
kazanmıştır (Gökçe vd., 2008). Bunlardan 17 Mart 2005 Kuzulu heyelanında 15 kişi yaşamını kaybetmiş ve 21 ev zarar görmüştür. (Gökçe vd., 2008; Duman vd., 2005; Gürsoy vd., 2006; Gökçeoğlu vd., 2005; Nefeslioğlu vd., 2008a; Yıldırım 2006; Yılmaz vd., 2006). Çalışma alanında bahsi geçen bu tarihlerin dışında da gerçekleşen pek çok heyelan uydu görüntüleri ve arazi çaışmaları ile tespit edilmiştir.

\section{Veri ve Yöntem}

Çalışmada heyelan envanterinin oluşturulmasında yüksek çözünürlüklü 2014 yılına ait Spot $(5 \mathrm{~m})$ ve yine aynı yıla ait çok yüksek çözünürlüklü Worldview (1 m) uydu görüntüleri kullanılmıştır. Harita Genel Komutanlığı 1:25000 ölçekli topoğrafya haritalarından çalışma alanına ait sayısal yükseklik modeli (10x10m) elde edilmiştir. Litoloji ve faylara ait bilgiler 1:25000 ölçekli MTA jeoloji haritaları sayısallaştrılarak oluşturulmuştur. Tüm verilerin sayısallaştırılmasında ve bu verilere ilişkin mekânsal analizlerde ArcGIS $10.1^{\circledR}$ yazılımı kullanılmıştır.

Yöntem olarak uydu görüntülerinden araziye ait biçim, doku, morfolojik ilintiler ve örüntüler gibi görüntü tanımlama özellikleri ile heyelan alanları belirlenmiştir. Arazi çalışmalarıyla heyelanların hem alansal hem de tiplerine ilişkin yersel doğrulamalar yapılmıştır. Bunun yanı sıra arazi çalışmaları ile uydu görüntülerinden ayırt edilemeyen heyelanlar ile uydu görüntülerinin algılandığı tarihten sonra meydana gelmiş heyelanlar belirlenmiştir. Topoğrafya haritasından elde edilen çözünürlükteki Sayısal Yükselti Modeli (SYM) ve yükseklik eğrileri ile heyelanların sayısallaştırması sırasında yapılan hatalar topoğrafyaya bağlı olarak giderilmiştir. SYM verisi aynı zamanda havzanın eğim $(30 \times 30 \mathrm{~m})$ değerlerinin hesaplanmasında kullanılmıştır. SYM verisinden havza içerisinde oluşturulan 2000 m2'lik dikdörtgen alanlar içindeki minimum ve maksimum farka karşılık gelen rölyef değerleri (30×30m) elde edilmiştir. Her bir heyelan başlangıç noktasındaki grid merkezine nokta atamaları yapılmıştır. Bulunduğu gridi temsil eden noktalara yükselti, rölyef ve eğim değeri bilgileri taşınarak veri matrisleri oluşturulmuştur. Bu veri matrisleri heyelan tipleri bazında (düşme, kayma, akma) sınıflandırılmıştır. Elde edilen verilerin eğim, yükselti ve rölyef karakteristikleri kernel yoğunluğuna göre dağılımları analiz edilmiştir. Litolojik birimler ile heyelan tipleri ilişkilendirilerek litolojik birimlerin heyelan tipleri içerisindeki yoğunlukları elde edilmiştir. Bunun yanı sıra, heyelanların aktif fayla olan mekânsal ilişkisi tamponlama (ing. buffer) analizleriyle incelenmiştir. Bu bakımdan fayı merkez alan 250 $\mathrm{m}$ tampon zonları oluşturulmuş ve bu zonlar içerisinde kalan heyelanların yoğunlukları tespit edilmiştir. Ayrıca heyelanların uzun eksenleri kısa eksenlerine oranlanarak heyelan tiplerine göre nasıl bir değişim gösterdiği incelenmiştir (Şekil 3).

\section{Bulgular}

\subsection{Heyelan Dağılımı ve Büyüklükleri}

Çalışma alanının \%13.2' sini oluşturan 433 heyelanın toplam alanı 51.94 km² dir. Havzanın en büyük heyelanı Koyulhisar heyelanı $\left(23.2 \mathrm{~km}^{2}\right)$ ile en küçük heyelanı $\left(0.004 \mathrm{~km}^{2}\right)$ havzanın kuzeyinde yer almaktadır (Şekil 4). Ekstrem büyüklükteki Koyulhisar heyelanı dâhil olmak üzere 18 heyelan $\left(23.2-5.1 \mathrm{~km}^{2}\right)$ göreceli olarak çok büyük, 25 heyelan büyük (5.1-1.0 km²), 137

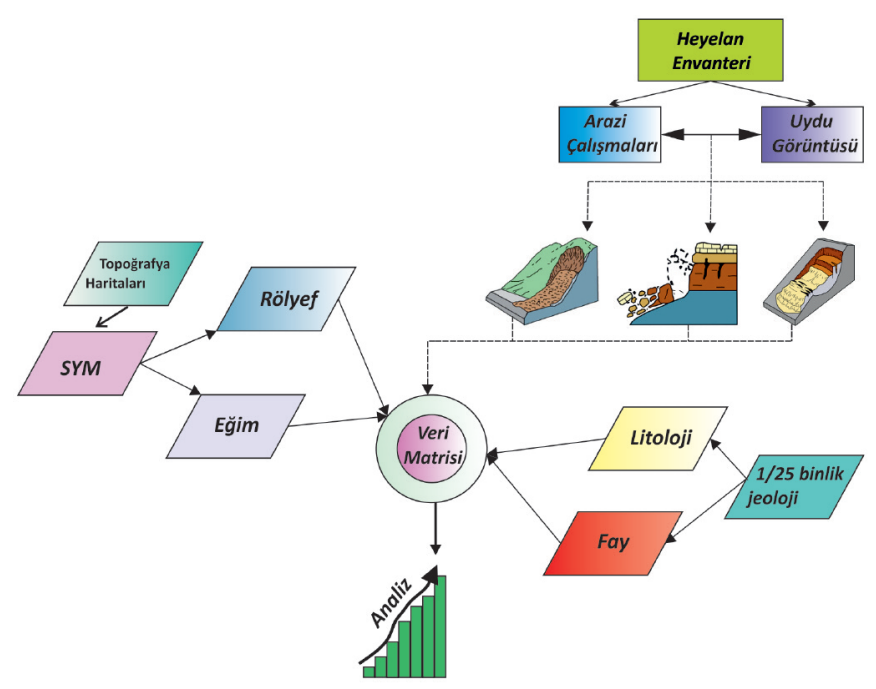

Şekil 3. Yönteme ilişkin akış şeması.

Figure 3. Flow chart of the methodology.

heyelan orta (1.0-0.1 km²), 234 heyelan küçük (0.1-0.001 km²) ve 19 heyelan ise $\left(<0.001 \mathrm{~km}^{2}\right)$ çok küçük boyuttadır. Kayma (108 adet), düşme (317 adet), akma (8 adet) (Şekil 4) olarak 3 ana tip altinda toplanan heyelanların \%92'sini $\left(47.7 \mathrm{~km}^{2}\right)$ kaymalar, \%5.1'ini (2.7 km²) düşmeler, \%3'ünü (1.5 km²) ise akmalar oluşturmaktadır. Havzadaki toplam heyelanların \%78.1'i havzanın kuzeyinde yer alırken \%21.9'u ise güneyinde yer almaktadır. Heyelan tiplerine bakıldığında düşmelerin havzanın kuzeybatısında kaymaların ise kuzeydoğusunda yoğunlaşth̆̆ görülmektedir (Şekil 5d). Bununla birlikte heyelan noktasal yoğunluğunun Umurca'nın kuzeydoğusundaki yamaçlarda arttğı gözlenirken (Şekil 6a) alansal bakımdan heyelan yoğunluklarının Koyulhisar çevresinde daha yüksek olduğu görülmektedir (Şekil 6b).

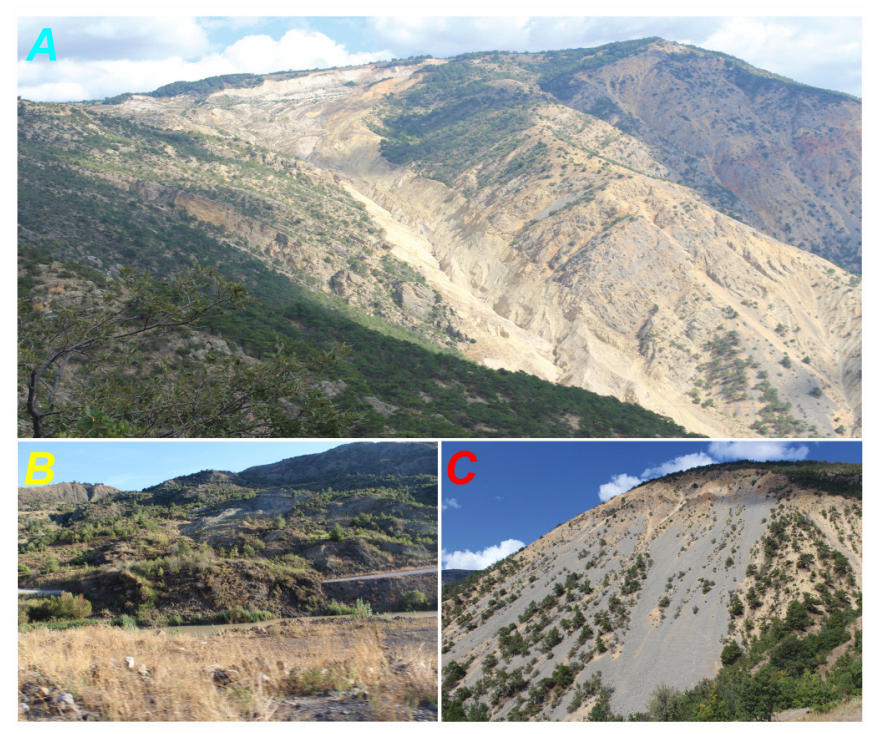

Şekil 4. Çalışma alanındaki heyelan tiplerine örnekler (A) Sugözü'ünde meydana gelen bir akma tipi heyelan (B) Kelkit Çayı yan yamaçlarındaki bir kayma tipinde bir heyelan (C) Umurca Köyünün kuzeydoğusundaki kaya düşmeleri. Figure 4. Examples of the landslide types in the study area (A) A flow-type landslide in Sugözü area (B) A Slide-type landslide in the side slopes of the Kelkit Creek (C) Rock falls in the northeast of the Umurca village.

Heyelan tiplerine göre heyelanların etki mesafesinin (ing. runout) belirlenmesi için heyelanların uzun ve kısa eksen oranları hesaplanmıştır (Şekil 7). Heyelan uzunluk-genişlik oranı değer- 

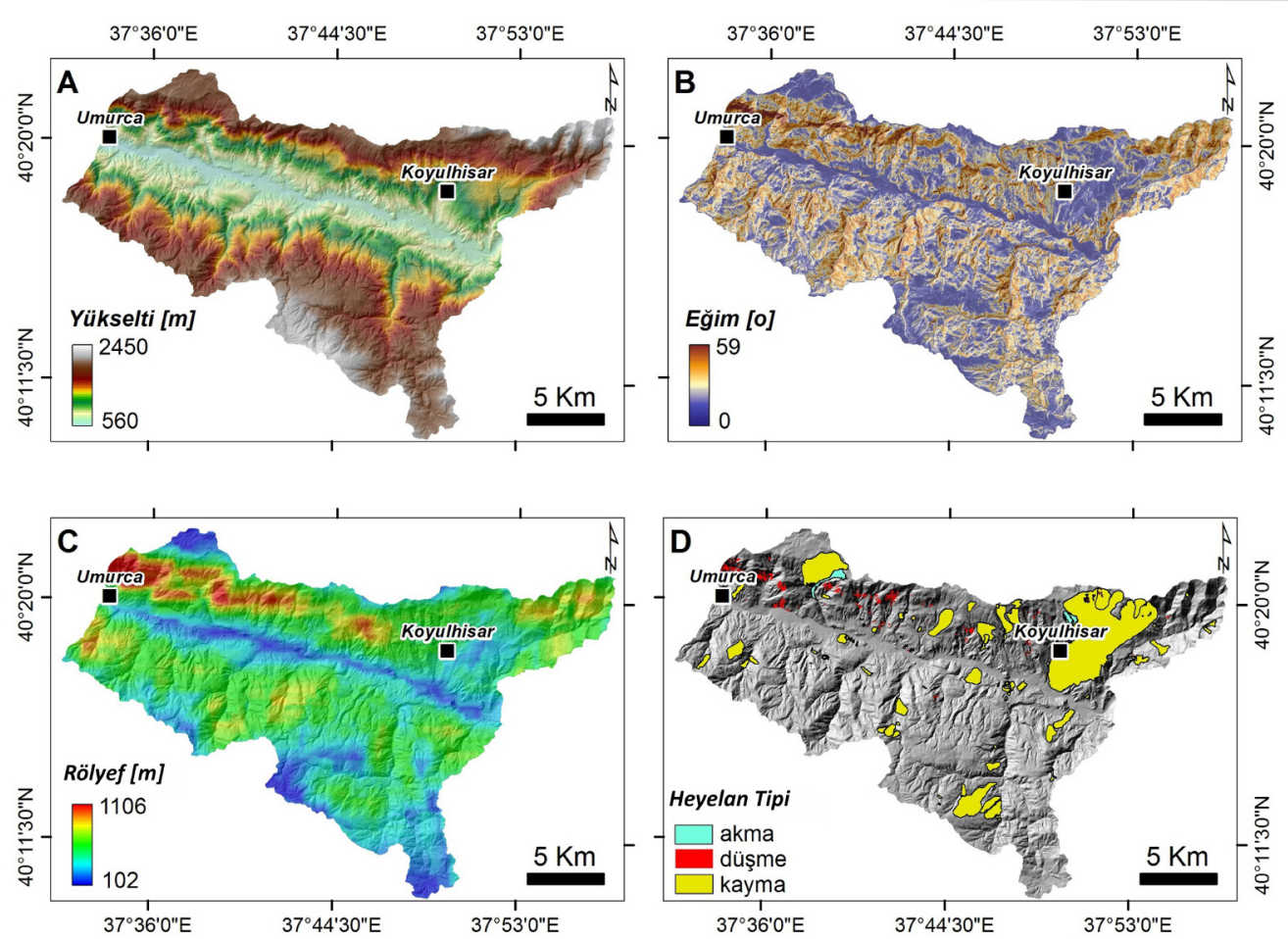

Şekil 5. Çalışmada kullanılan başlıca topoğrafik parametreler ve heyelan tipleri. (A) Yükseklik, (B) Eğim, (C) Topoğrafik rölyef, (D) Heyelan tipleri dağıış haritası. Figure 5. Main topographic parameters used in the study and the landslide types. (A) Elevation, (B) Slope, (C) Topographic relief and (D) Distribution map of the landslide types.
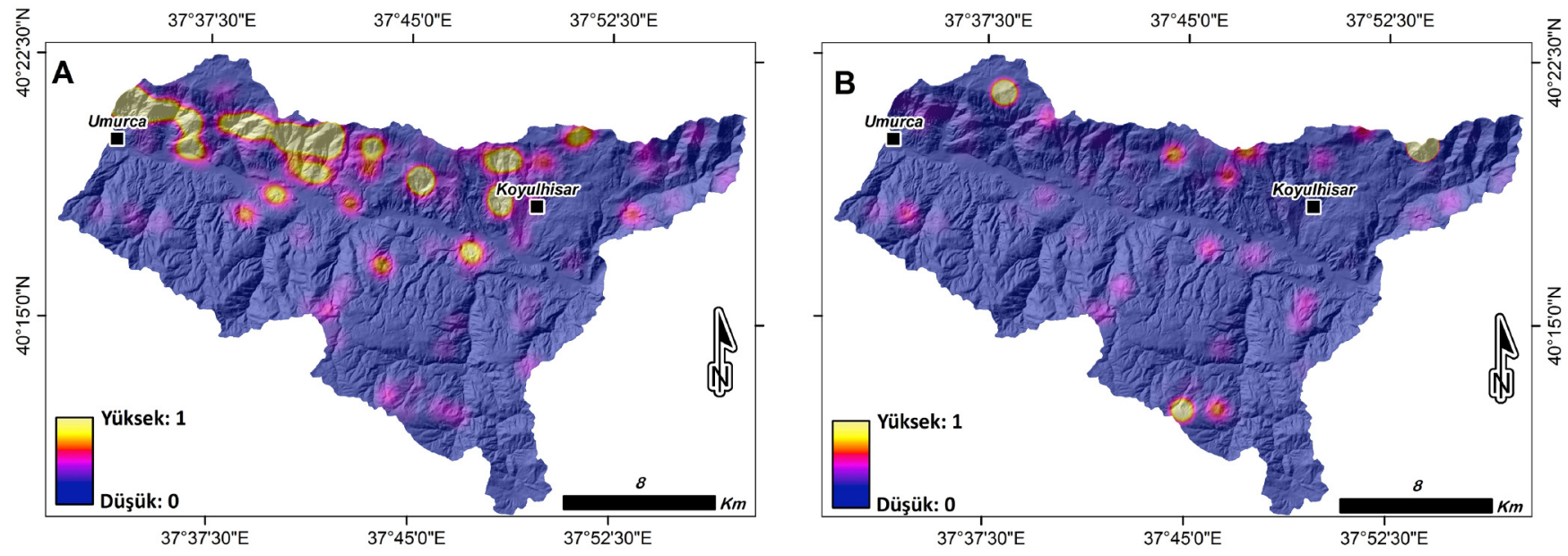

Şekil 6. Noktasal (A) ve alansal (B) heyelan yoğunluk haritaları.

Figure 6. Landslide point (A) and area density maps.

lerinin 1-12 arasında değiştiği belirlenmiştir. Söz konusu bu oranlar heyelan tiplerine göre belirgin şekilde farklılıklar göstermektedir. Oransal farklar özellikle kayma ve düşme tipindeki heyelanlarda artarken, akma ve düşmeler arasındaki farklar göreli olarak daha düşüktür (Şekil 7a). Toplam heyelan etki mesafesinin akma ve düşmelerde daha yüksek değerlerde olduğu görülmüştür. Bu değerler akmalarda maksimum 4.2, düşmelerde ise $10.8^{\prime}$ dir. Düşmelerde değerlerin varyansı diğer heyelan tiplerine göre daha yüksektir. Kaymaların varyansı ise en düşüktür. Kayma tipindeki heyelanlarda uzunluk-genişlik oranı değerleri maksimum 4.4'tür. Kaymalar, düşme ve akmalara göre daha düşük oran aralıklarında görülmektedir.

\subsection{Bölgesel Heyelan Dağılımını Kontrol Eden Faktörler}

\subsubsection{Topografya}

Çalışmada heyelan oluşumunun ve dağılımının topoğrafya ile

olan ilişkisini ortaya koymak için alanda gerçekleşmiş farklı tip heyelanlar için kernel yoğunluk kestirimine göre normalize edilmiş yükselti, rölyef, eğim dağılımları analiz edilmiştir (Şekil 8). Değerler incelendiğinde heyelan alanlarının ortalama yükselti değerleri (1307 m) havzanın ortalama yükselti değerlerinden (1283 m) yüksek olmasına rağmen yükselti modu bakımından havzaya göre daha düşük olduğu görülmüştür. Belirli seviyelerde küçük değişimler göstermesine karşın heyelanlı alanların ortalama rölyef değerleri havzanın ortalama rölyef değerlerinden yüksektir. Nitekim heyelanların rölyef modu havzanın rölyef modundan düşüktür. Eğim değerlerinde ise; heyelandan etkilenmemiş topoğrafik alanlar hem ortalama hem de mod bakımından heyelandan etkilenmiş alanlara göre yüksek değerlerde oldukları görülmüştür. Fakat bu durum heyelan tiplerine göre farklılık göstermektedir. Heyelan tiplerinin yükselti ortalamaları birbirine yakın olmakla beraber aralarında ortalama olarak 2 m gibi küçük bir yükselti farkı görülmektedir. Mod değerleri düşme ve kayma tipi heyelanlarda yakın değerlerde iken 

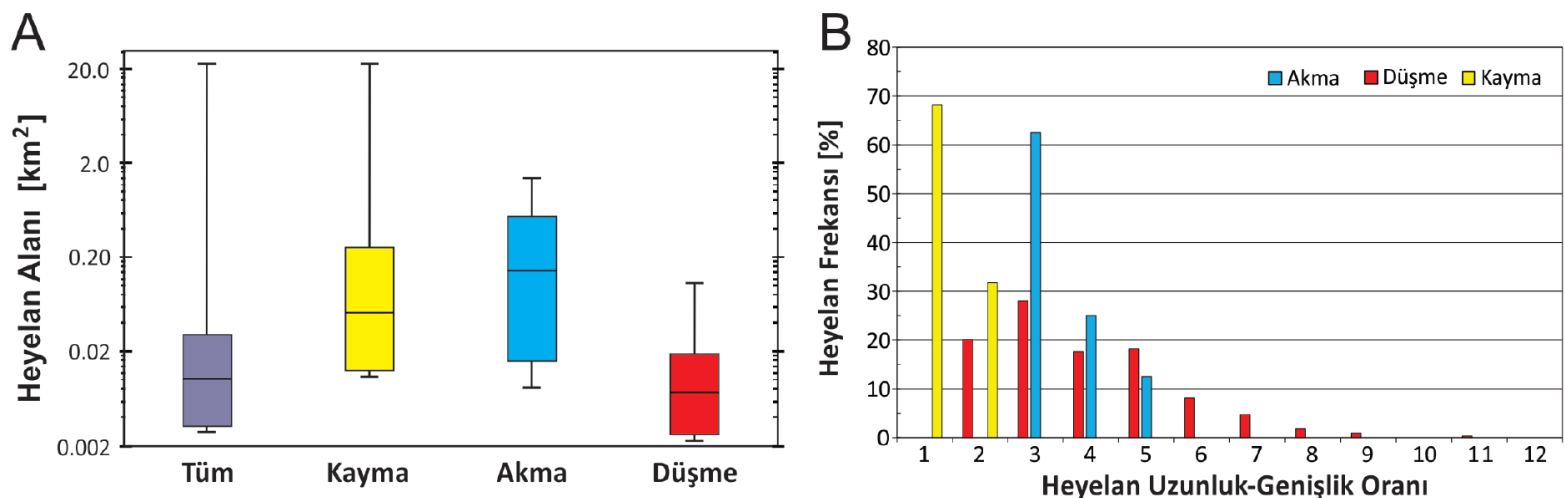

Şekil 7. Heyelan ana tiplerine göre alansal dağılımları (A) ve uzunluk genişlik oranları (B). Şekil A'da yer alan heyelan alanının ölçeği logaritmik olarak (Log10) verilmiştir.

Figure 7. The spatial distribution of the main types of landslide (A) and length width ratios (B). Please note the log scale (Log10) in Figure A.

akmalarda daha yüksek değerlerdedir. Rölyef değerleri bakımından düşmeler, kayma ve akmalara göre daha yüksektir. Düşme tipi heyelanların mod değeri 600-650 m değerleri arasında görülürken, 900-950 m aralıklarında ikinci bir yükselim göstererek çift hörgüçlü bir dağılım sergilemektedir. Akmalar ise; kaymalara göre daha düşük rölyef değerleri göstermiştir. Eğim değerlerine bakıldığında düşmeler akma ve kaymalara göre çok yüksek değerlerde görülmektedir. Düşmeler aynı zamanda akma ve kaymalardan farklı olarak sola çarpıklık göstermektedir (Şekil 8). Bu tip çarpıklık farklarının nedeni heyelan tiplerinin farklı eğim koşullarında meydana gelmesinden kaynaklanmaktadır.

\subsubsection{Litoloji}

Heyelan tipine göre her bir heyelanın kaynak alanından alınan
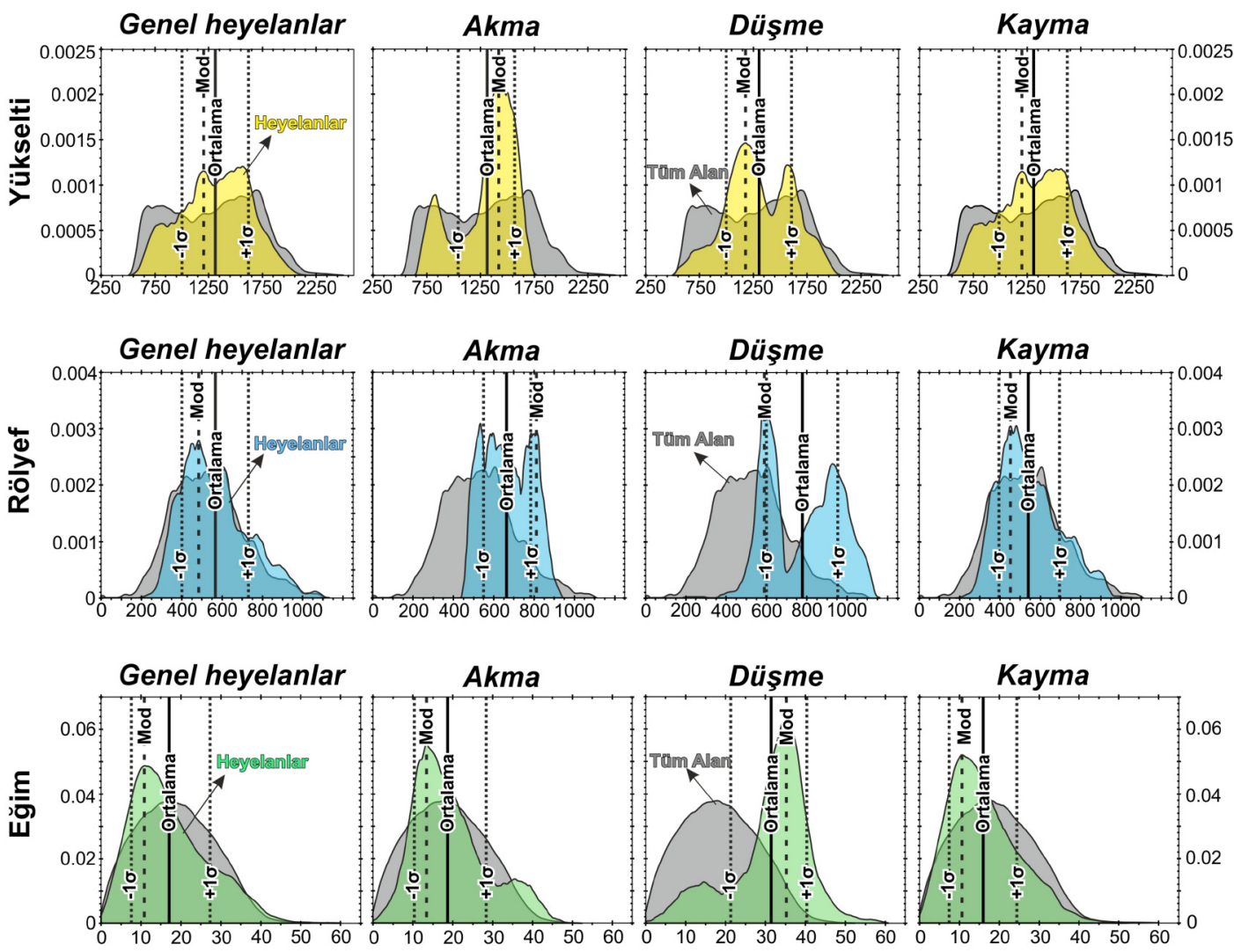

litolojik bilgiler incelendiğinde; havzada en fazla bulunan volkanit-çökel kaya (Eosen) birimleridir. Alansal olarak heyelanların en fazla gerçekleştiği (\%40.2) özellikle Koyulhisar heyelanın büyük bir çoğunluğunu içeren bu birimlerde daha çok kayma türündeki heyelanlar mevcuttur. Aynı zamanda akma ve düşmelerin de küçük oranlarda bu birimler üzerinde gerçekleştiği görülmüştür. Kireçtaşı (Maestrihtiyen) litolojik biriminde heyelanların \%24.9'u gerçekleşmektedir. Akmaların ve düşmelerin en fazla, kaymaların ise bir kısmının gerçekleştiği bu birimlerde küçük - büyük her bir heyelan tipini görmek mümkündür. Bu birimler aynı zamanda sayı bakımından en çok heyelanın meydana geldiği (246 heyelan) litolojik yapıdır. Çalışma sahasının daha çok kuzeydoğusunda Sugözü ve kuzeybatısında Koyulhisar paleo heyelanlarının geliştiği alanlardaki hâkim litoloji bazalt (Pliyosen) birimlerinde ise akma, düşme ve kayma tipi heyelanlar gelişmiştir. Havzanın güneyindeki serpantinitlerde (Üst
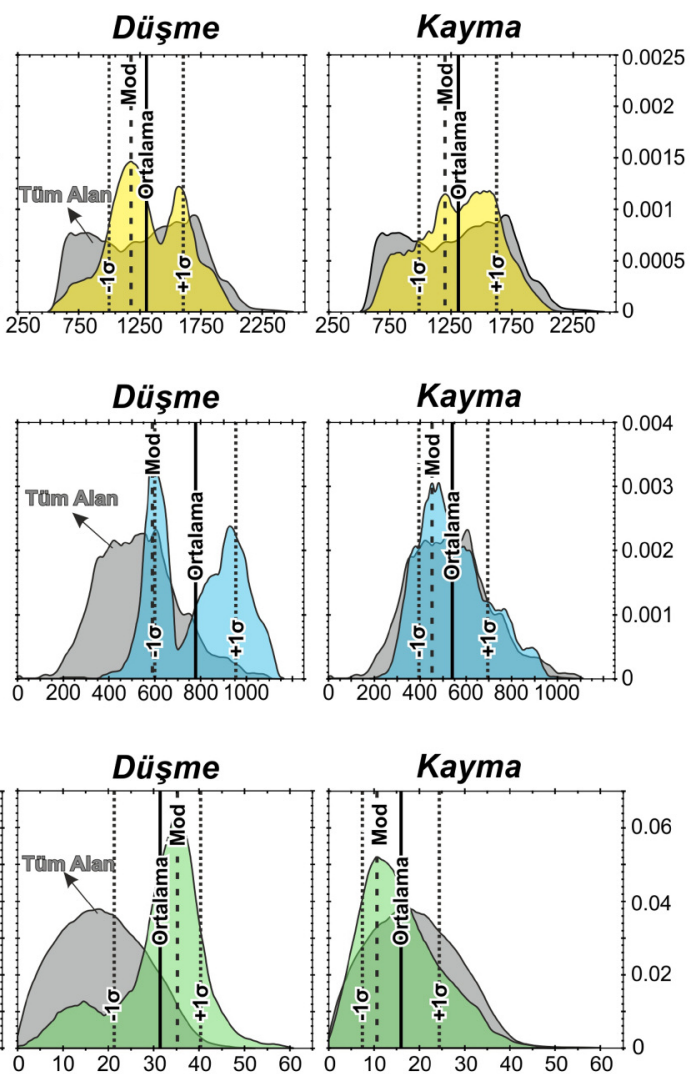

Şekil 8. Farklı heyelan tipleri için yükseklik, rölyef ve eğim değerlerinin olasılık dağılım kestirimleri. $\pm 1 \sigma$ (standart sapma) değerleri toplam verinin \%70’ine karşılık gelmektedir.

Figure 8. Probability density estimates of elevation, topographic relief and slope values for different landslide types. $\pm 1 \sigma$ (standard deviation) values corresponds to $70 \%$ of the total data set. 
Kretase) ise kaymaların bir kısmının ve düşmelerin de çok az yoğunlukta bu birimlerde meydana geldiği görülmüştür.

KAF'ın kuzeyinde faya paralel bir şekilde bir hat boyunca konumlanan ve heyelanların \%6'sını oluşturan volkanit-çökel kaya (Üst Kretase) birimlerinde akma, düşme ve kayma tipinde heyelanlar gelişmiştir. Bunların dışında çalışma sahasında kumtaşı-çamurtaşı-kireçtaşı (Üst Paleosen) birimlerinde çok düşük oranlarda düşme ile kaymaların geliştiği, Şist (Paleozoyik), alüvyon (Kuvaterner) çakıltaşı-kumtaşı-çamurtaşı (Alt miyosen), kiltaşı (Alt Eosen-Orta Eosen), melanj (Üst Kretase), şist (Permiyen-Triyas) birimlerinde ise sadece kayma tipi heyelanların geliştiği görülmektedir (Tablo 1).

\subsubsection{Yapı}

Havza genelinde bakıldığında heyelanlar fayın kuzey bölümünde daha yoğun olarak görülmektedir. Kuzey bölümünde görülen heyelanların büyük çoğunluğunu oluşturması ile birlikte daha büyük heyelanlar havzanın bu kesiminde yer almak- tadır (Şekil 9a ve b). Havzada genel olarak heyelan yoğunlukları 8-9 km arasındaki zonlarda yoğunlaşmıştır Bu zonlardaki heyelan yoğunluğu fayın hem kuzeyinde hem de güneyinde görülmektedir (Şekil 9a). Heyelan sayısının ise 3-4 km arasındaki zonlarda daha fazla olduğu ve bunların çoğunluğunun düşmelerden oluştuğu görülmektedir (Şekil 9b).

\section{Tartışma ve Sonuç}

Tektonik denetimli Kelkit Çayı'nın oluşturduğu son derece çizgisel ve derin vadi, yükseklik farkları dolayısıyla depremler kadar kütle hareketleri bakımından da son derece aktif bir alandır. Bu alanda gelişen heyelanları denetleyen faktörleri ele aldığımız bu çalışma alanında özellikle Umurca ve Koyulhisar arasında Türkiye'nin en büyük anakaya heyelanlarından birisi olan Koyulhisar heyelanı ( 23.2 km²), 2005 yılının bahar döneminde 15 kişinin ölümüyle sonuçlanan Sugözü heyelanı ve plato yamaçlarında iç içe gelişmiş pek çok heyelan bulunmaktadır. Farklı tipte heyelanların tespit edildiği alanda egemen he-

Tablo 1. Litolojik birimlerin heyelan tipine göre yoğunlukları.

Table 1. Density of lithological units with respect to the landslide type.

\begin{tabular}{|c|c|c|c|c|c|c|c|c|c|c|c|c|c|c|c|c|c|}
\hline \multicolumn{3}{|c|}{ Litolojik Birim } & \multicolumn{3}{|c|}{ Bütü̈n Havza } & \multicolumn{3}{|c|}{ Büttün Heyelanlar } & \multicolumn{3}{|c|}{ Akma } & \multicolumn{3}{|c|}{ Düsme } & \multicolumn{3}{|c|}{ Kayma } \\
\hline Adı & Sembol & Devir & $\mathrm{Km}^{2}$ & $\%$ & $\begin{array}{l}\text { Havza içindeki } \\
\text { Yoğunluğu }\end{array}$ & $\mathrm{Km}^{2}$ & $\%$ & $\begin{array}{c}\text { Havza içindeki } \\
\text { Yoğunluğu }\end{array}$ & $\mathrm{Km}^{2}$ & $\%$ & $\begin{array}{l}\text { Havza içindeki } \\
\text { Yoğunluğu }\end{array}$ & $\mathrm{Km}^{2}$ & $\%$ & $\begin{array}{l}\text { Havza içindeki } \\
\text { roğunluğu }\end{array}$ & $\mathrm{Km} \mathrm{m}^{2}$ & $\%$ & $\begin{array}{l}\text { Havza içindeki } \\
\text { Yoğunluğu }\end{array}$ \\
\hline Alüvyon & $Q_{a}$ & Kuvaterner & 7,9 & 2,0 & 0,02 & 0,03 & 0,05 & 0,0001 & & & & & & & 0,03 & 0,06 & 0,0001 \\
\hline Bazalt & Teb & Pliyosen & 43,2 & 11,0 & 0,1 & 7,59 & 14,6 & 0,02 & 0,28 & 18,7 & 0,0007 & 0,19 & 7,0 & 0,0005 & 7,1 & 14,9 & 0,02 \\
\hline Çakaltaş-Kumtasıl-Çamurta. & a. Tkk & Alt Miyosen & 13,7 & 3,5 & 0,03 & 0,19 & 0,4 & 0,0005 & & & & & & & 0,2 & 0,4 & 0,0005 \\
\hline Kiltası & Tok & Üst Oligosen-Alt Miyosen & 0,3 & 0,08 & 0,001 & & & & & & & & & & & & \\
\hline çakıltaşı & Toi & Oligosen-Alt Miyosen & 1,7 & 0,4 & 0,004 & & & & & & & & & & & & \\
\hline Volkanit-çökel Kaya & Tyh & Eosen & 129,5 & 32,9 & 0,3 & 20,91 & 40,2 & 0,05 & 0,04 & 2,4 & 0,00009 & 0,03 & 1,22 & 0,00009 & 20,8 & 43,7 & 0,05 \\
\hline Andezit & Toc & Lutesiyen & 1,4 & 0,3 & 0,003 & & & & & & & & & & & & \\
\hline Kiltaşı & Ta & Alt Eosen-Orta Eosen & 1,2 & 0,3 & 0,003 & 0,06 & 0,1 & 0,0001 & & & & & & & 0,1 & 0,12 & 0,0001 \\
\hline Kumtassı-Çamurtassı-Kiresta; & Tdu & Ust Paleosen & 2,9 & 0,7 & 0,01 & 0,75 & 1,4 & 0,002 & & & & 0,01 & 0,23 & 0,00002 & 0,7 & 1,6 & 0,002 \\
\hline Kireştaşı & $\operatorname{Tg}$ & Paleosen & 0,4 & 0,1 & 0,001 & & & & & & & & & & & & \\
\hline Andezit & $\mathrm{kkv}$ & Santoniyen-Maestrihtiyen & 0,99 & 0,3 & 0,003 & & & & & & & & & & & & \\
\hline Volkanit-çökel Kaya & $\mathrm{km}$ & Üst Kretase & 43,7 & 11,1 & 0,11 & 3,12 & 6,0 & 0,008 & 0,19 & 12,5 & 0,0005 & 0,39 & 14,2 & 0,001 & 2,5 & 5,3 & 0,01 \\
\hline Kirecttası & $\mathrm{kri}$ & Maestrintiyen & 53,5 & 13,6 & 0,14 & 12,92 & 24,9 & 0,03 & 1,01 & 66,4 & 0,003 & 2,11 & 76,9 & 0,005 & 9,8 & 20,5 & 0,02 \\
\hline Melanj & Kt & Ust Kretase & 3,2 & 0,8 & 0,01 & 0,21 & 0,4 & 0,0005 & & & & & & & 0,2 & 0,4 & 0,0005 \\
\hline Serpantinit & Tas & Ust Kretase & 83,8 & 21,3 & 0,21 & 5,44 & 10,5 & 0,01 & & & & 0,01 & 0,5 & 0,00004 & 5,4 & 11,4 & 0,01 \\
\hline sist & Ptd & Permiyen-Triyas & 3,04 & 0,8 & 0,01 & 0,16 & 0,3 & 0,0004 & & & & & & & 0,2 & 0,3 & 0,0004 \\
\hline Kireçtaşı & Ktk & Paleozoyik-Mesozzyik & 0,05 & 0,01 & 0,0001 & & & & & & & & & & & & \\
\hline şist & Kts & Paleozoyik & 3,6 & 0,9 & 0,01 & 0,59 & 1,14 & 0,002 & & & & & & & 0,6 & 1,2 & 0,002 \\
\hline Toplam & & & 394,1 & 100,0 & 1,0 & 51,98 & 100 & 0,126 & 1,5 & 100 & 0,004 & 2,7 & 100 & 0,007 & 47,7 & 100 & 0,12 \\
\hline
\end{tabular}

A

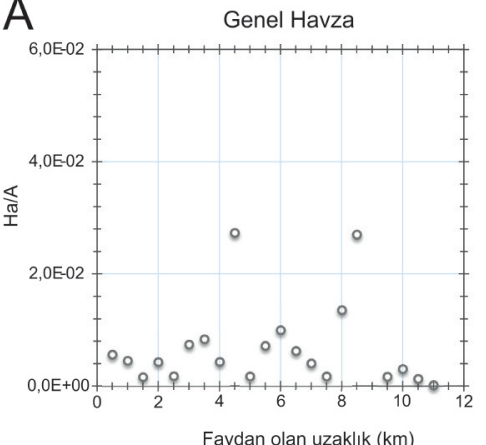

B

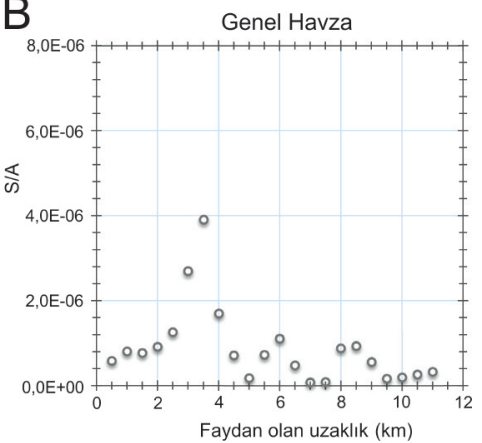

Havza kuzeyi
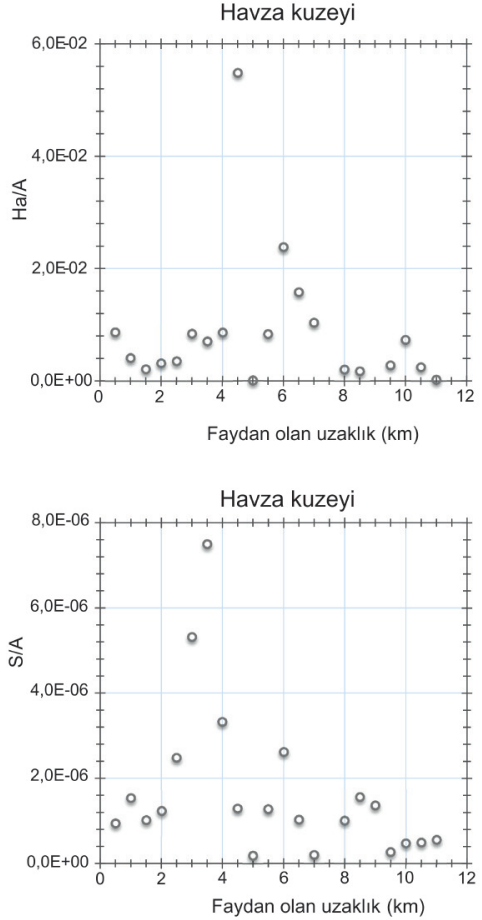

Havza güneyi

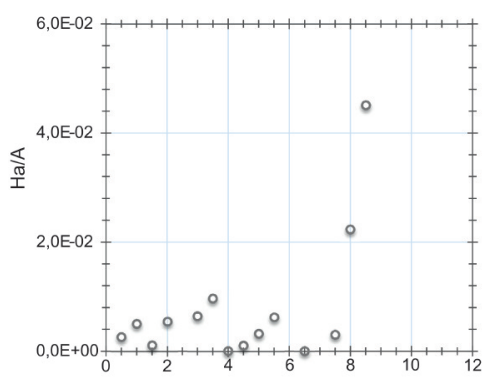

Faydan olan uzaklık $(\mathrm{km})$

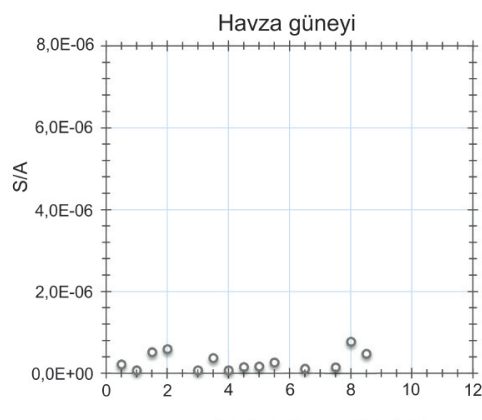

Faydan olan uzaklık $(\mathrm{km})$

Şekil 9. Faydan olan uzaklıklara göre heyelan alan (A) ve sayı yoğunluğunun (B) azalımı.

Figure 9. Decay of landslide area (A) and number density (B) with distance from fault. 
yelan tipi kayma ve akmalar olarak belirlenmiştir. Heyelan dağılımı açısından vadinin kuzey ve güney yamaçları arasındaki farklılık dikkat çekicidir. Çalışma alanında heyelanların büyük bir kısmının vadinin kuzey aklanında geliştiği belirlenmiştir (Şekil $5 d$ ve 6 ). Güney kesimde yoğunluğu düşen heyelanların Kelkit Vadisi yan yamaçlarından ziyade, geride dağlık alanda yer almaktadır ve toplam heyelanlı alan bakımından en yüksek değerlere Bakacak Tepe'nin (1906 m) güney kesiminde rastlanılmaktadır. Vadinin her iki kesiminde ortaya çıkan dağılım ve yoğunluk değerlerinin farklıı̆ı̆ının ana nedeni doğrultu atım bileşenli Kuzey Anadolu Fayı'na bağlı olarak ortaya çıkan litolojik kontrasttır. Fayın her iki bloğunda farklılık gösteren litolojik birimlerden kuzeyde yüzeylenen Eosen ve Üst Kretase volkanitçökel kaya birimleri heyelan yoğunluğu değerlerinin en yüksek olduğu birimlerdir. Çalışmada litolojinin yanı sıra yapı da bir faktör olarak ele alınmıştr. Bu bakımdan bölgedeki en önemli yapısal unsur Kuzey Anadolu Fayı ile faya olan uzaklıktaki noktasal ve alansal heyelan yoğunluğu karşılaştırılmıştır. Bu karşılaştırma sonucunda heyelan dağılımının faydan bağımsız olduğu (Şekil 9) buna karşın faydan uzaklığın ilk bir kaç kilometresinde alansal olarak daha küçük heyelanların fay tarafindan kontrol edildiği düşünülmektedir. Bu belirsizlik, ilk bir kaç kilometrede üstsel olarak azalan yoğunluk değerlerinin daha sonraki kilometrelerde bağımsız davranarak bu korelasyonun dışında olmasından kaynaklanmaktadır. Fakat fayın belirli büyüklükteki heyelanlar üzerindeki kontrolünün varlığını ortaya koyabilmek için ileriki çalışmalarda heyelan sıklık-büyüklük eğrileri üreterek çalışma daha detaylı olarak ele alınmalıdır. Buna karşın fayın her iki bloğunda benzer litolojilerde heyelan yoğunluk değerlerinin kuzey kesimde yine yüksek olduğu gözlenmektedir. Bu durum geçmişte gerçekleşmiş depremlerin yüzey kırığı ilerleme yönü ile de ilişkilendirilebilir. Dor vd. (2008) Kuzey Anadolu Fayı'nda yaptı̆̆ çalışmada 1943 ve 1944 kırıklarında homojen litolojik birimlerde yüzey kırığının ilerlediği yönde jeomorfolojik süreçlerin (flüvyal ve kolüvyal süreçlerin) farklılaştğını ve deformasyonun ve buna bağlı anomalilerin kırık ilerleme yönünde olduğunu ortaya koymuşlardır. Sahanın batısında benzer bir ilişki Nefeslioğlu vd. (2008a) tarafindan fayın her iki bloğunda farklılık gösteren heyelan duyarlılık haritası ile de ortaya konmuştur. Bu yönüyle ana fayın dolaylı ve doğrudan etkisinin bloklar arasındaki heyelan yoğunluk değerlerindeki farklılığın nedeni olduğu söylenebilir.

Çalışma sahasında kaymaların volkanit-çökel kayalarda ve düşme ve akmaların ise kireçtaşı litolojik biriminde gerçekleştiği görülmüştür. Genellikle kireçtaşı birimlerinde görülen akma ve düşmelerde; düşmelerin fiziksel çözünmenin etkisinde gerçekleştiği, akmaların ise özellikle Sugözü heyelanında da görüldüğü üzere üst seviyedeki karların ani erimeleri sonucu suların kireçtaşı birimlerinden yeraltına sızması ve alt seviyedeki kütlelerin suya doygun hale gelmesiyle oluşmaktadır (Gökçeoğlu vd., 2005; Gürsoy vd., 2006; Nefeslioğlu vd., 2008b; Yıldırım 2006; Yılmaz vd., 2006).

Topoğrafik bakımdan heyelanların gelişimi ve dağılımı üzerindeki rolleri incelendiğinde genel olarak akmalar üzerinde topoğrafik yükselti ve eğimin etki denetiminin yüksek olduğu görülmüştür. Düşmelerde yükselti, eğim ve rölyefin etki denetiminin kayma ve akmalara göre daha yüksek olduğu, kaymalarda ise belirgin bir topoğrafik faktör denetiminin akma ve düşmelere göre olmadığı görülmüştür. Kaymaların diğer heyelan tiplerine göre genel havza topoğrafyasını yansıttı̆ı görülm- üştür. Bunun ana nedeni; ekstrem büyüklükteki kayma tipindeki Koyulhisar heyelanının ( $\left.23.2 \mathrm{~km}^{2}\right)$ toplam heyelanlı alanların \%45'ini temsil etmesi ve heyelan gerçekleştikten sonra Koyulhisar yerleşiminin bulunduğu yamaçların eğim oranın düşmesi, kaymaların topoğrafik değerlerinin de saha ortalamasına benzer bir dağılım göstermesidir. Mekânsal dağılım açısından topoğrafik faktörlere bakıldığında; yamaç eğim ve topoğrafik rölyef değerlerinin havzanın batısında ve özellikle bu kısımda Kelkit Vadisinin kuzey kesiminde arttğı gözlenmektedir (Şekil 5). Buna karşılık heyelan yoğunluk değerlerindeki artış da dikkat çekicidir. Özellikle kaya düşmelerinin ve yer yer de kayma tipinde büyük ana kaya heyelanlarının yer aldığı bu kesimde akarsu derine kazma oranları da yüksektir.

Tektonik bakımdan aktif bir alan olan araştırma sahasındaki ana yükseklik farklarına sebep olan bölgesel yükselime karşılık (Zabcı vd. 2011) akarsuyun yatağını derinleştirmesi havzada belirgin rölyef farklılığına neden olmuştur. Bu farklar ile özellikle Kelkit Vadisinin yan yamaçlarında gelişen heyelanların sürekli gençleştiği, bir başka ifadeyle var olan kütlelerin topuklarında meydana gelen akarsu aşındırmasıyla heyelanların tekrardan aktif hale geçerek iç içe birçok heyelanı meydana getirdiği saha çalışmaları ile de gözlenmiştir. Bu alanda meydana gelen Sugözü heyelanı bu sürece verilebilecek iyi örneklerden biridir. Gökçeoğlu vd. (2005) tarafindan Sugözü heyelanının oluşum ve mekanizmasının tanımlandığı çalışmada, Sugözü’nde gelişen heyelanın daha önce alanda var olan paleo bir heyelanın gövdesinde yer aldığı ve 2005 yılının bahar döneminde ani kar erimelerine bağlı olarak geliştiği ifade edilmiştir. Alanda gelişen birçok heyelanın (ör. Aklan heyelanı (Koyulhisar yerleşiminin kuzeyi)) benzer mekanizmayla tetiklendiği bilinmektedir (Yılmaz, 2009). Özellikle Mart ve Nisan aylarında ani kar erimelerinin gerçekleştiği ve bunların bazı heyelanları tetiklediği saha çalışmaları sırasında yerel idare sorumluları ve yöre halkı ile yapılan görüşmelerde de belirtilmiştir. Buna karşılık Türkiye'nin birçok alanında olduğu sorumlu kurum ve kuruluşlar tarafindan iyi kayıt tutulmaması veya bunların birçoğunun eksik ve yetersiz oluşu heyelanı tetikleyen (ör. sismik ve/veya hidro-meteorolojik tetikleyiciler) ana faktörün ve bunun şiddetinin bilinmemesine neden olmaktadır. Bu bakımdan çalışmada güncel olarak bir kaç heyelan dışında ana tetikleyici faktör hakkında bilinenler limitlidir.

Kelkit Vadisinin aşağı kesiminde heyelan dağılım deseninin ve oluşumlarını kontrol eden faktörlerin değerlendirildiği bu çaışmada; alanları 0.004-23.2 km² arasında değişen farklı büyüklük ve tipte (ağırlıklı moloz akmaları, kaya düşmeleri ve kaymaları gibi) yaklaşık 433 adet kütle hareketi haritalanmıştır. Çalışmada, bu heyelanların: (1) Kuzey Anadolu Fay'ının Kelkit segmentinin kuzeyindeki blokta yoğunlaştğı ve bu blokta yer alan heyelanların güneye göre daha yıkıcı olduğu, (2) kireçtaşı ve volkanik-sedimenter birimlerin dokanaklarında ve faylanma dolayısıyla paralanmış zayıflık zonlarında yoğunlaştikları, (3) belirli bir topoğrafik eğim ve rölyef değerleri arasında dağıldıkları ve jeomorfolojik açıdan geliştikleri alanların rastlantısal olmadığı (4) üst kesimlerde daha düze yakın plato aklanında ve paleo-heyelan topoğrafyaları içerisinde biriken karların ani erimesinin bu sürecin heyelanların tetiklenmesindeki ana neden olduğu ortaya konmuştur. 


\section{Katkı Belirtme}

Bu çalışma İstanbul Üniversitesi Bilimsel Araştırmalar Projeleri Birimi (BAP) tarafindan 55865 nolu proje ile desteklenmiştir.

\section{Kaynakça}

Bayrakdar, C., ve Görüm, T. (2012). "Yeşil Göl heyelanı'nın jeomorfolojik özellikleri ve oluşum mekanizması". Türk Coğrafya Dergisi, (59), 1-10.

Blöthe, J. H., Korup, O., and Schwanghart, W. (2015). "Large landslides lie low: Excess topography in the Himalaya-Karakoram ranges". Geology, 43(6), 523-526.

Brabb, E.E., Pampeyan, E.H., and Bonilla, M.G., (1978). "Landslide susceptibility in San Mateo County, California. US Geological Survey Misc. Field Studies Map," MF-360, map at $1: 62,500$ scale.

Carrara, A., 1983. "A multivariate model for landslide hazard evaluation." Mathematical Geology 15, 403-426.

Dai, F. C., and Lee, C. F. (2001). "Frequency-volume relation and prediction of rainfall-induced landslides." Engineering geology, 59(3), 253-266.

Dai, F. C., Xu, C., Yao, X., Xu, L., Tu, X. B., and Gong, Q. M. (2011). "Spatial distribution of landslides triggered by the $2008 \mathrm{Ms}$ 8.0 Wenchuan earthquake," China. Journal of Asian Earth Sciences, 40(4), 883-895.

Dor, O., Yildirim, C., Rockwell, T. K., Ben-Zion, Y., Emre, O., Sisk, M., and Duman, T. Y. (2008). "Geological and geomorphologic asymmetry across the rupture zones of the 1943 and 1944 earthquakes on the North Anatolian Fault: possible signals for preferred earthquake propagation direction." Geophysical Journal International, 173(2), 483-504.

Duman T.Y., Nefeslioğlu H., Gökçeoğlu C., ve Sönmez H. (2005) 17/03/2005 Kuzulu (Sivas-Koyulhisar) heyelanı, Maden Tetkik ve Arama Genel Müdürlüğü Jeoloji Etütleri Dairesi, Hacettepe Üniversitesi.

Erdem, F. (1987). "Kelkit Havzasında Sediment Erozyon İlişkileri," Jeomorfoloji Dergisi, Sayı 15, sayfa 65-73, Ankara

Gokceoglu, C., Sonmez, H., Nefeslioglu, H. A., Duman, T. Y., and Can, T. (2005). The 17 March 2005 Kuzulu landslide (Sivas, Turkey) and landslide-susceptibility map of its near vicinity. Engineering Geology, 81(1), 65-83.

Gorum, T., Gonencgil, B., Gokceoglu, C., and Nefeslioglu, H. A. (2008). "Implementation of reconstructed geomorphologic units in landslide susceptibility mapping: the Melen Gorge (NW Turkey)." Natural Hazards, 46(3), 323-351.

Gorum, T., Fan, X., van Westen, C. J., Huang, R. Q., Xu, Q., Tang, C., and Wang, G. (2011). "Distribution pattern of earthquake-induced landslides triggered by the 12 May 2008 Wenchuan earthquake." Geomorphology, 133(3), 152-167.

Gorum, T., Korup, O., van Westen, C. J., van der Meijde, M., Xu, C., and van der Meer, F. D. (2014). "Why so few? Landslides triggered by the 2002 Denali earthquake, Alaska." Quaternary Science Reviews, 95, 80-94.

Gökçe, O., Özden, Ş., ve Demir, A., (2008) “Türkiye'de afetlerin mekânsal ve istatiksel dağılımı, T.C Bayındırlık ve İskan Bakanlığı Afet İşleri Genel Müdürlüğü Afet Etüt ve Hasar Tespit Daire Başkanlığı," Ankara.

Gökçeoğlu, C., ve Ercanoğlu, M. (2001). “Heyelan duyarlılık haritalarının hazırlanmasında kullanılan parametrelere ilişkin belirsizlikler." Yerbilimleri/Hacettepe Üniversitesi Yerbilimleri Uygulama ve Araştırma Merkezi Dergisi, 5(23), 189-206.

Guzzetti, F., Carrara, A., Cardinali, M., and Reichenbach, P. (1999). "Landslide hazard evaluation: a review of current techniques and their application in a multi-scale study," Central Italy. Geomorphology, 31(1), 181-216.

Guzzetti, F., Peruccacci, S., Rossi, M., and Stark, C. P. (2007). "Rainfall thresholds for the initiation of landslides in central and southern Europe." Meteorology and atmospheric physics, 98(3-4), 239-267.

Gürsoy, H., Tatar, O., Mesci, L., ve Koçbulut F., (2005). “Kuzey Anadolu Fay Zonu üzerinde gelişen 17 Mart 2005 Kuzulu Mahallesi Heyelanının (Sugözü Köyü - Koyulhisar, Sivas) jeolojik, jeomorfolojik özellikleri ve mevcut risk durumu," ATAG-9: Aktif Tektonik Araştirma Grubu 9. Toplantısı, 22-24 Eylül.

Gürsoy, H., Tatar, O., Koçbulut, F., Mesci, B.L., Akpınar, Z., Tunçer D., ve Yaman, S., (2006) "Kuzulu (Sugözü-Koyulhisar, Sivas) heyelan bölgesinin temel jeolojik özellikleri: heyelan sahasında gözlenen tektonik yapıların heyelanın gelişiminde rolü var mı?." ATAG10 - Aktif Tektonik Araştırma Grubu 10. Toplantisı, s. 44-45, Sivas.

Hungr, O., Leroueil, S., and Picarelli, L. (2014). "The Varnes classification of landslide types, an update." Landslides, 11(2), 167-194.

Keçer, M ve Tüfekçi, K. (1986). "Kuzey Anadolu Fayına Bağlı Olarak Neotektonik Dönemde Oluşan Suşehri Havzası'nın Evrimi." Jeomorfoloji Dergisi, Sayı 14, sayfa 57-63, Ankara

Korup, O., and Stolle, A. (2014). "Landslide prediction from machine learning." Geology Today, 30(1), 26-33.

Larsen, M. C., and Torres-Sánchez, A. J. (1998). "The frequency and distribution of recent landslides in three montane tropical regions of Puerto Rico." Geomorphology, 24(4), 309331.

MTA Genel Müdürlüğü (2011), Türkiye 1:250.000 ölçekli Türkiye Jeoloji Haritası, MTA Ankara.

Nefeslioglu, H. A., Duman, T. Y., and Durmaz, S. (2008a). "Landslide susceptibility mapping for a part of tectonic Kelkit Valley (Eastern Black Sea region of Turkey)." Geomorphology, 94(3), 401-418.

Nefeslioglu, H. A., Gokceoglu, C., and Sonmez, H. (2008b). "An assessment on the use of logistic regression and artificial neural networks with different sampling strategies for the preparation of landslide susceptibility maps." Engineering Geology, 97(3), 171-191.

Nefeslioglu, H. A., Sezer, E. A., Gokceoglu, C., and Ayas, Z. (2013). "A modified analytical hierarchy process (M-AHP) approach for decision support systems in natural hazard assessments." Computers and Geosciences, 59, 1-8.

Owen, L. A., Kamp, U., Khattak, G. A., Harp, E. L., Keefer, D. K., and Bauer, M. A. (2008). "Landslides triggered by the 8 October 2005 Kashmir earthquake." Geomorphology, 94(1), 1-9.

Regmi, N. R., Giardino, J. R., and Vitek, J. D. (2014). Characteristics of landslides in western Colorado, USA. Landslides, 11(4), 589-603.

Tatar, O., Poyraz, F., Gürsoy, H., Cakir, Z., Ergintav, S., Akpınar, Z., and Polat, A. (2012). "Crustal deformation and kinematics of the Eastern Part of the North Anatolian Fault Zone (Turkey) from GPS measurements." Tectonophysics, 518, 55-62. 
TUiK (Türkiye İstatistik Kurumu) 2014, Adrese dayalı nufüs kayıt sistemi. http://www.tuik.gov.tr/PreTablo.do?alt_id=1059

van Westen, C. J., Van Asch, T. W., and Soeters, R. (2006). "Landslide hazard and risk zonation-why is it still so difficult?." Bulletin of Engineering geology and the Environment, 65(2), 167-184.

Varnes, D. J. (1958). "Landslide types and processes." Highway Research Board Special Report, (29).

Wu, C. H., Chen, S. C., and Chou, H. T. (2011). "Geomorphologic characteristics of catastrophic landslides during typhoon Morakot in the Kaoping Watershed, Taiwan." Engineering Geology, 123(1), 13-21.

Yıldırım, A. (2006). "Koyulhisar-Kuzulu (Sivas) Heyelanının Jeomorfolojik Etüdü." (The geomorphological survey of Koyulhisar-Kuzulu (Sivas) Landslide). Doğu Coğrafya Dergisi, 11(15).

Yilmaz, A., Oral, A., ve Bilgiç, T. (1985). "Yukarı Kelkit Çayı yöresi ve güneyinin temel jeoloji özellikleri ve sonuçları." MTA raporu 112s.

Yılmaz I. (2009). “A case study from Koyulhisar (Sivas-Turkey) for landslide susceptibility mapping by artificial neural networks," Bull. Eng. Geol. Environ. 68, s. 297-306.

Yılmaz, I., Ekemen, T., Yildirim, M., Keskin, İ., and Özdemir, G. (2006). "Failure and flow development of a collapse induced complex landslide: the 2005 Kuzulu (Koyulhisar, Turkey) landslide hazard." Environmental geology, 49(3), 467-476.

Zabci, C., Akyüz, H. S., Karabacak, V., Sançar, T., Altunel, E., Gürsoy, H., and Tatar, O. (2011). "Palaeoearthquakes on the Kelkit Valley segment of the North Anatolian Fault, Turkey: Implications for the surface rupture of the historical $17 \mathrm{Au}$ gust 1668 Anatolian earthquake." Turkish Journal of Earth Sciences, 20(4), 411-427. 